
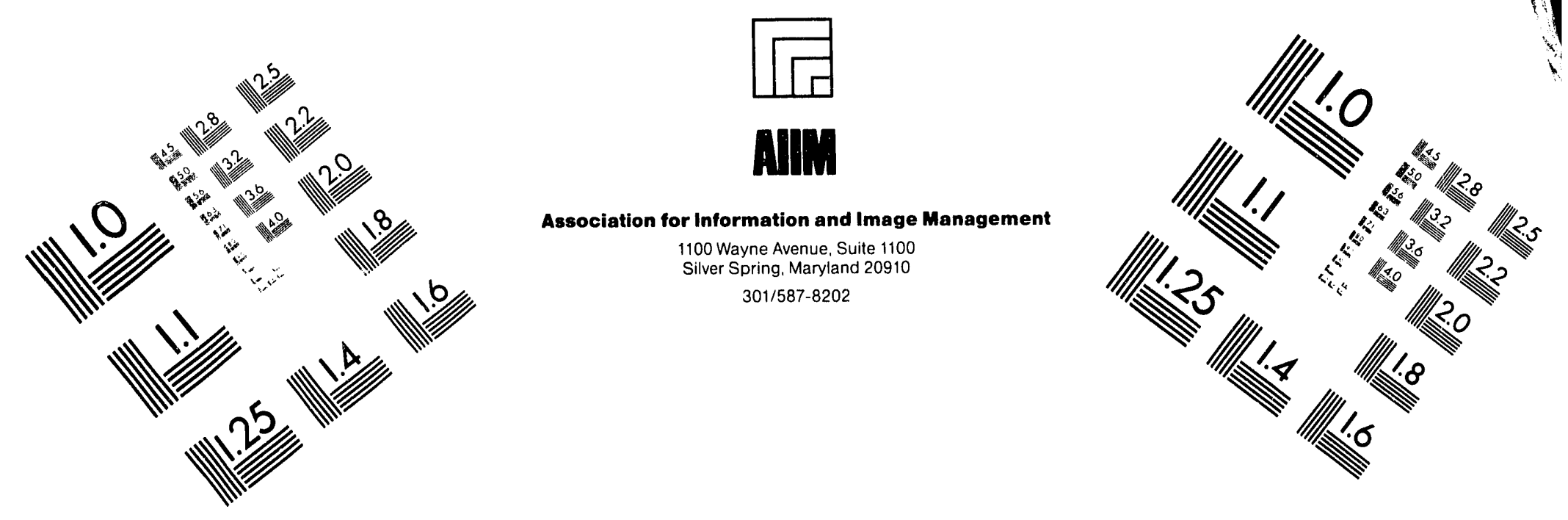

\title{
Centimeter
}

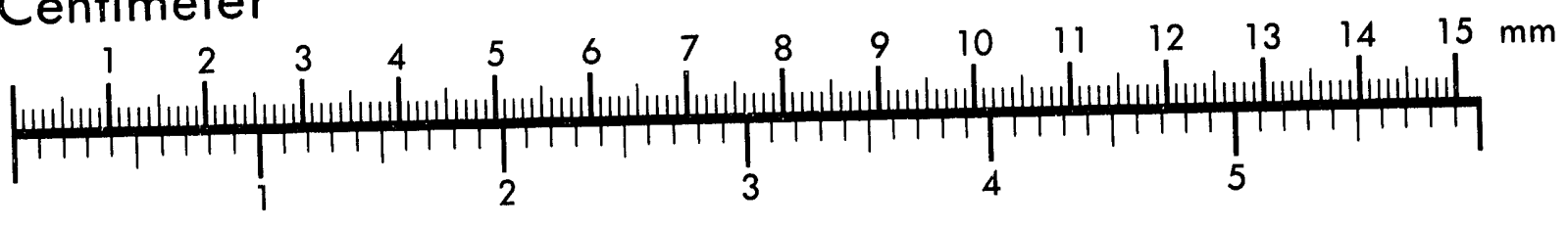
Inches
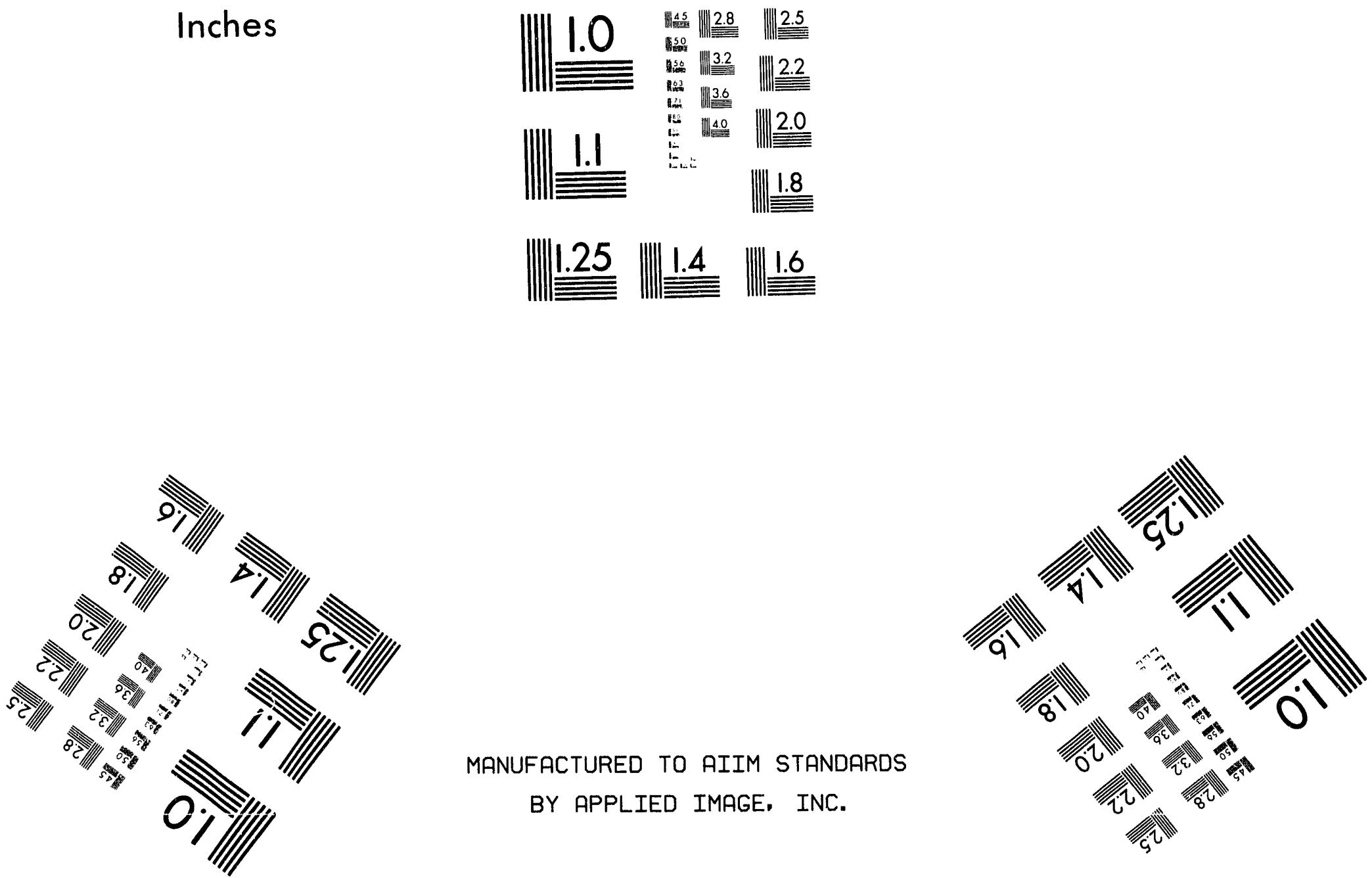

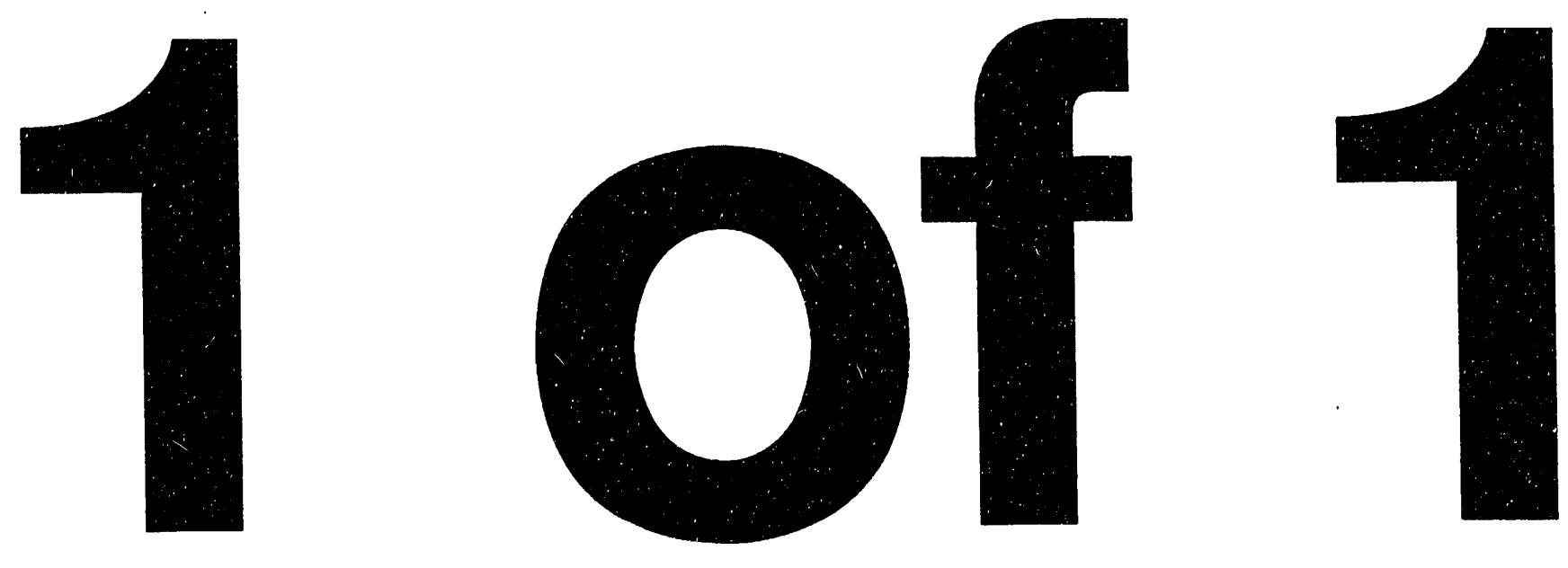


\section{DURABILITY OF GLASSES VITRIFIED FROM HIGH COPPER FEED IN THE 774 RESEARCH MELTER (U)}

by

M. K. Andrews

Westinghouse Savannah River Company

Savannah Fiver Site

Aiken, South Carolina 29808

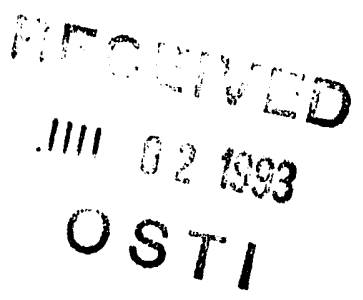

DOE Contract No. DE-AC09-89SR18035

This paper was prepared in connection with work done under the above contract number with the U. S.

Department of Energy. By acceptance of this paper, the publisher and/or recipient acknowledges the U.S. Government's right to retain a nonexclusive, royalty-free license in and to any copyright covering this paper, along with the right to reproduce and to authorize others to reproduce all or part of the copyrighted paper.

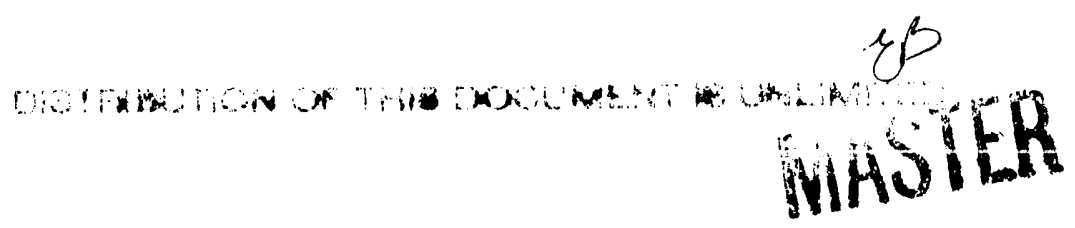




\section{DISCLAIMER}

This report was prepared as an account of work sponsored by an agency of the United States Government. Neither the United States Government nor any agency thereof, nor any of their employees, makes any warranty, express or implied, or assumes any legal liability or responsibility for the accuracy, completeness, or usefulness of any information, apparatus, product, or process disclosed, or represents that its use would not infringe privately owned rights. Reference herein to any specific commercial product, process, or service by trade name, trademark, manufacturer, or otherwise does not necessarily constitute or imply its endorsement, recommendation, or favoring by the United States Government or any agency thereof. The views and opinions of authors expressed herein do not necessarily state or reflect those of the United States Government or any agency thereof.

This report has been reproduced directly from the best available copy.

Available to DOE and DOE contractors from the Office of Scientific and Technical Information, P. O. Box 62, Oak Ridge, TN 37831; prices available from (615) $576-8401$.

Available to the public from the National Technical Information Service, U. S. Department of Commerce, 5285 Port Royal Rd., Springfield, VA 22161. 
WESTINGHOUSE SAVANNAH RIVER COMPANY SAVANNAH RIVER TECHNOLOGY CENTER
TSRC-RP-93-642, Rev. 0

Keywords: DWPF, melter,
composition

Retention Time: Permanent

CC: L. M. Papouchado, 773-A

E. W. Holtzscheiter, 773-A

E. F. Duhn, 773-A

N. E. Bibler, 773-A

J. T. Carter, 704-1T

L. F. Landon, 704-T

C. T. Randall, 704-T

S. A. Budenstein, 704-1T DC\&RM， 773-52A

GTG (9)

April 28, 1993

To: $\quad$ M. J. Plodinec, 773-A

From: M. K. Andrews, 773-A MKA

\section{DURABIIITY OF GIASSES VITRIFIFD FROM HIGH COPPER FEED IN THE 774 RESEARCH MEITER (U)}

\section{Introduction and summary}

Small scale crucible studies were performed by Schumacher to examine the effects of formate and nitrate on glass redox at high copper levels.1 The results of the crucible studies were used to determine the regions where copper precipitates in the glass.2 However, durability tests were not performed on the glass samples.

Studies were performed in the 774 Research Melter using a simulated feed from the Purex 4 Campaign in the Integrated DWPF Melter system (IDMS). Three runs were performed with this simulated feed. The first used the feed as it was received to determine a baseline. The results from the second and third campaigns were compared to the baseline. The second run increased the copper concentration. The third increased the copper and formate concentrations. The purpose of these experiments was to investigate melter performance and glass durability using a feed with increased copper concentration.

The Purex 4 feed did not contain the target amounts of sludge and Precipitate Hydrolysis Aqueous (PHA). Less than $20 \%$ of the feed slurry consisted of simulated sludge, making it a low wasteloading feed. The use of this feed with significantly more copper added than anticipated in the DWPF, showed no indication of copper precipitating in the melter. In addition, the glasses produced during the campaigns were more durable than the benchmark glass. 


\section{Experimental}

The 774 Research Melter is a slurry-fed joule heated melter with two pairs of Inconel electrodes providing the power to maintain a melt pool temperature of $1150^{\circ} \mathrm{C}$. The cylindrical melt chamber is eight inches in diameter and six inches deep and holds approximately ten kilograms of glass. Two additional heaters are located in the melter above the melt pool to provide supplemental heat which increases the melt rates by vaporizing water from the slurry feed. Glass pouring is initiated by tilting the entire melter. The glass flows from the melt pool through a riser cut in the refractory, and out a heated pour spout into one liter stainless steel cans.

Three melter runs were performed for this campaign. The first rur contained only the simulated sludge as received and was performed to determine the quality of the glass before additional copper was added. The second run was identical to the first except that additional copper, in the form of copper formate, was added. The third run also contained copper formate, but formic acid was also added. For all three runs, the melter was fed continuously for approximately 30 hours at a nominal rate of $21 \mathrm{~mL} / \mathrm{min}$. The first and third runs produced six cans of glass while the second run produced only four. Each can holds between 2.5 and $3 \mathrm{~kg}$ of glass. The glass used for analysis was taken from the bottom portion of each of the cans produced.

If the copper precipitates in the glass and settles on the bottom of the melter, it can create a path of lower resistance for the current flow of the electrodes. Significant deposits can eventually lead to failure of the electrodes. Therefore suring each of the melter runs, the current between the electrodes was monitored. At the completion of each run, a specially designed device was used to sample the glass from the bottom of the melt pool. The device was a hollow tube that was inserted into the melter through the feed nozzle opening until it reached the bottom of the melter. A vacuum was pulled to force the glass frorr the bottom of the melt pool up through the tube. The melt pool glass was removed from the tube and submitted to the Analytical Development section (ADS) to determine if any copper had settled to the melter floor.

The chemical composition of several cans of glass produced during the melter runs was determined. For each can of glass prouced, the $\mathrm{Fe}^{+2} / \Sigma \mathrm{Fe}$ ratio was measured. This was compared to the redox ratio predicted by the formate minus nitrate concentrations. 3 The durability of the glass was assessed by subjecting samples of the glass to the Product Consistency Test (PCT). 4 The PCT is a crushed glass leach test that measures the releases of boron, sodium, and lithium from the glass in $90^{\circ} \mathrm{C}$ ASTM Type 1 water after immersion for seven days. The average concentraticns were compared to the results for the Environmental Assessment (EA) glass.5 The EA glass was run simultaneously with the samples and was used as a benchmark. 


\section{Results and Discussion}

Between ten and seventeen kilograms of glass was produced during each melter run. Glass taken from each can poured during the three campaigns was analyzed by ADS. The composition of the last can from each melter run is given in Table 1 . Only the composition of the last can is presented since it should be the most representative of the melter feed. The copper concentration in Runs 2 and 3 is higher than would be expected during normal melter operation, and the sludge loading of the melter feed used was lower than normally encountered. Therefore, the glass produced during these runs can be considered a worst case.

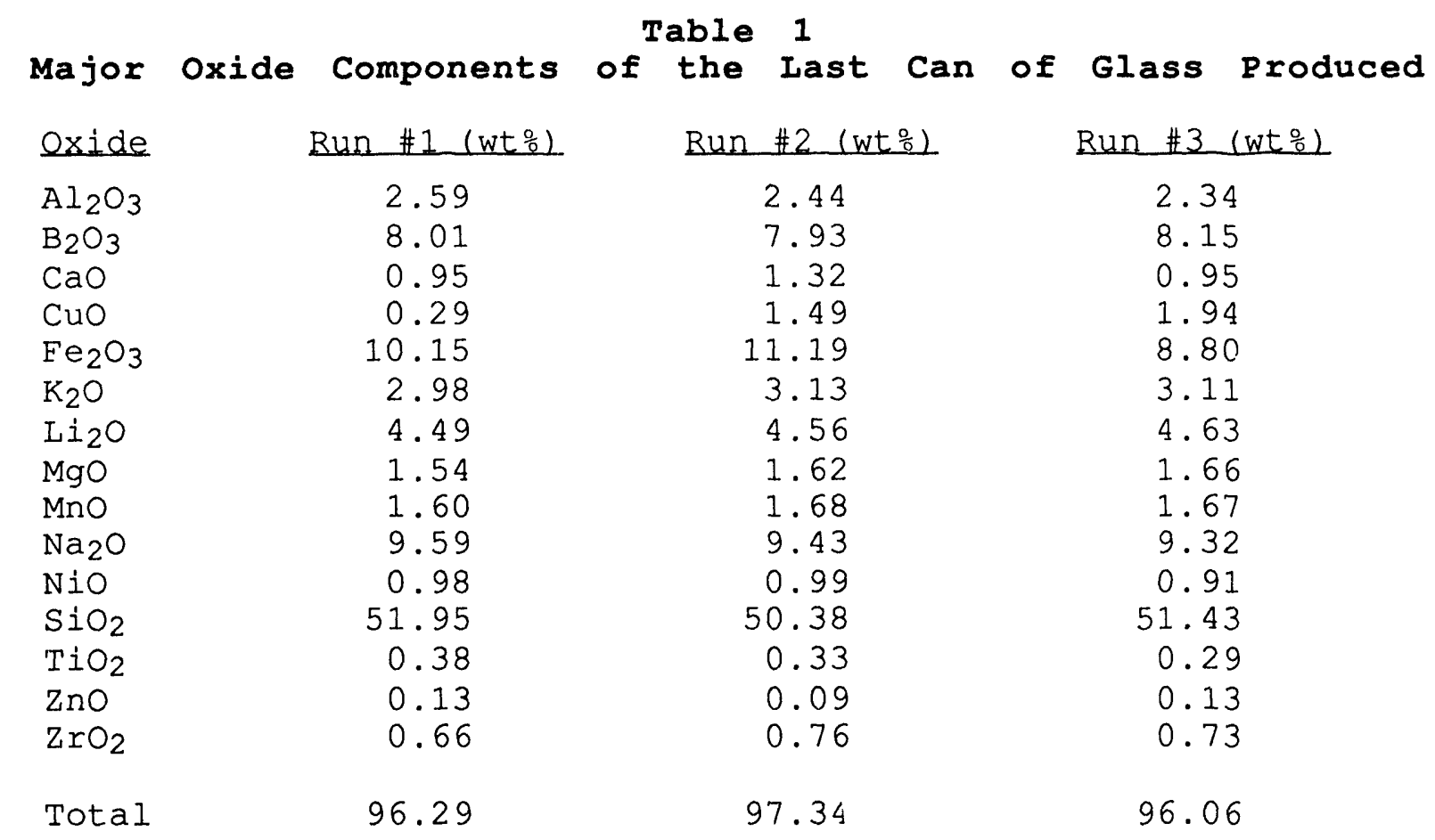

To verify that the copper was not precipitating on the melter floor, the current required to maintain the melt at the operating temperature of $1150^{\circ} \mathrm{C}$ was monitored. rhe current as a function of time for each melter run are presented in Figures 1, 2, and 3 . No significant increase in the current occurred indicating that the copper was not creating a path of lower resistance on the melter floor.

Further verification was obtained using the melt pool sampler which was able to remove a small amount of glass from the bottom of the melt pool after the final can of each run was poured. This glass was analyzed to determine if copper had precipitated on the bottom of the melter. Less copper was detected in the melt pool samples than in the last can poured during the run indicating that copper was not accumulating on the bottom of the melt pool. 

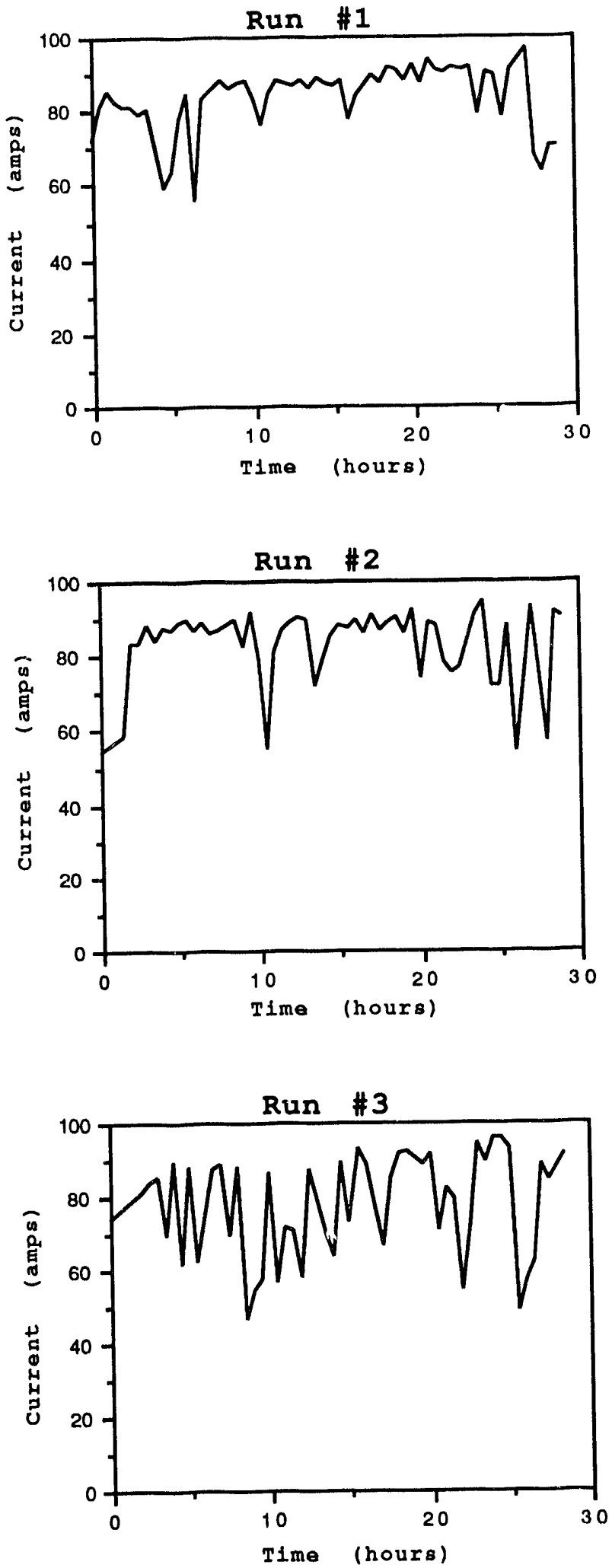

Figures 1,2 and 3 - Current as a function of time 
Glass samples from the selected cans were examined by Scanning Electron Microscopy (SEM). Trevorite and acmite crystals were detected, along with a few small metallic copper particles. Significant copper precipitation was not detected by SEM.

Table 2 presents the formate and nitrate concentrations of the slurry feed for each run, along with the redox ratio $\left(\mathrm{Fe}^{+2} / \Sigma \mathrm{Fe}\right)$ for each can poured during the runs. It has been found that for formate minus nitrate values below 0.9 , the redox ratios are below 0.1 .6 The latter cans in Run 3, which have an $\mathrm{F}-\mathrm{N}$ value of 0.81 , have redox ratios above 0.1 . Crucibles studies using the same type of feed also encountered this variation. 3

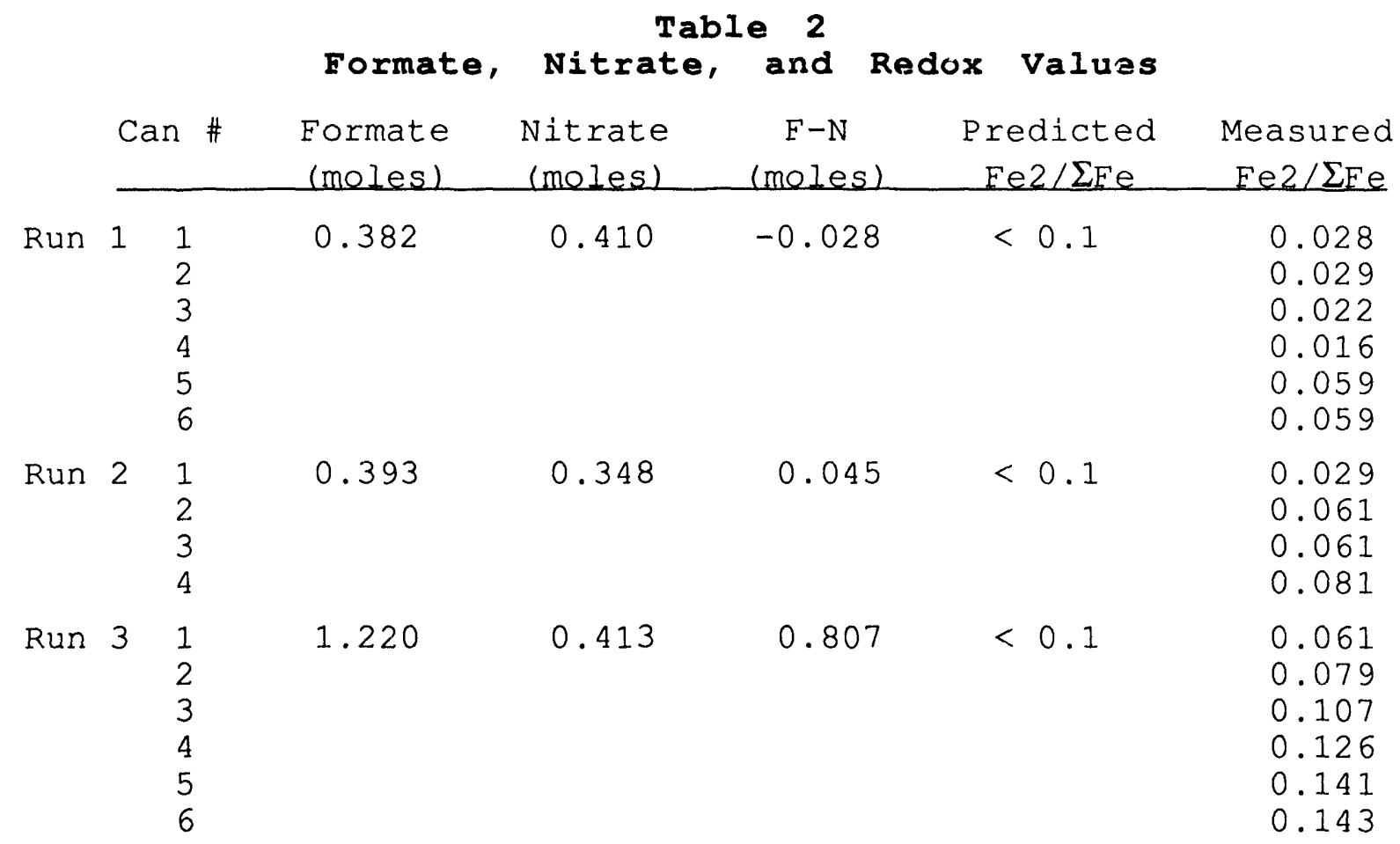

The acceptability of the glass can be assessed by comparing its durability (as measured by the PCT) with that of the EA glass. Triplicate glass samples, including the EA glass, were analyzed and the analytical results averaged. The average boron, sodium, and lithium releases for each can poured and for the EA glass are given in Table 3 . The results must be less than two standard deviations below the EA glass to meet the current repository specifications. Each can produced during the three melter runs did meet this specification.

Figure 4 shows the average boron release for the cans poured during each run. The results are plotted as a function of time, calculated as the time from the start of the run until the time when the can was removed from the melter. The average boron release of EA glass is also included. 


\begin{tabular}{|c|c|c|c|c|}
\hline & \multirow{2}{*}{\multicolumn{4}{|c|}{\begin{tabular}{l}
\multicolumn{2}{c}{ Table 3} \\
PCT Results
\end{tabular}}} \\
\hline & & & & \\
\hline & Can \# & $\begin{array}{l}\text { B Release } \\
\text { (ppm) }\end{array}$ & $\begin{array}{c}\text { Na Release } \\
\text { (ppm) }\end{array}$ & $\begin{array}{c}\text { Li Release } \\
(\text { ppm })\end{array}$ \\
\hline Run 1 & $\begin{array}{l}1 \\
2 \\
3 \\
4 \\
5 \\
6\end{array}$ & $\begin{array}{l}15.78 \\
18.58 \\
42.69 \\
66.26 \\
96.42 \\
80.31\end{array}$ & $\begin{array}{r}56.29 \\
55.09 \\
99.57 \\
140.81 \\
196.13 \\
167.97\end{array}$ & $\begin{array}{l}11.88 \\
14.49 \\
30.57 \\
46.39 \\
66.30 \\
57.53\end{array}$ \\
\hline Run 2 & $\begin{array}{l}1 \\
2 \\
3 \\
4\end{array}$ & $\begin{array}{r}27.21 \\
29.98 \\
36.75 \\
196.82\end{array}$ & $\begin{array}{r}67.00 \\
74.49 \\
90.99 \\
373.61\end{array}$ & $\begin{array}{r}22.28 \\
23.97 \\
28.80 \\
141.32\end{array}$ \\
\hline Run 3 & $\begin{array}{l}1 \\
2 \\
3 \\
4 \\
5 \\
6\end{array}$ & $\begin{array}{l}48.31 \\
53.79 \\
68.96 \\
84.61 \\
73.71 \\
78.63\end{array}$ & $\begin{array}{l}117.19 \\
119.79 \\
154.19 \\
203.56 \\
144.95 \\
175.82\end{array}$ & $\begin{array}{l}37.90 \\
41.01 \\
52.17 \\
62.95 \\
50.74 \\
58.24\end{array}$ \\
\hline & & 537.42 & 1569.76 & 179.31 \\
\hline
\end{tabular}

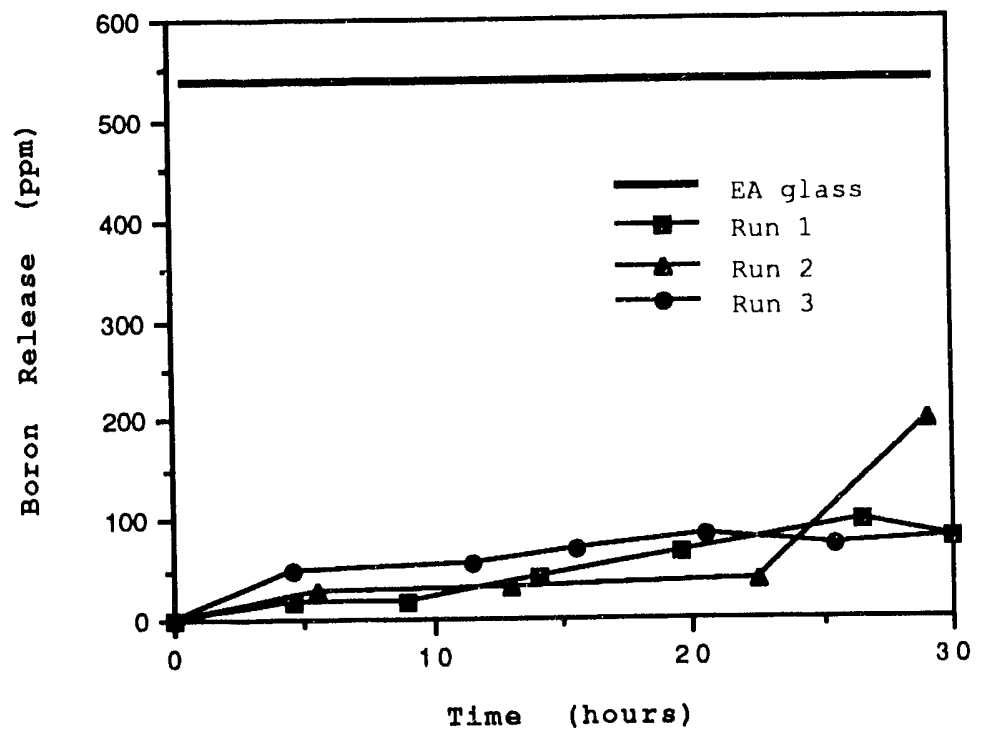

Figure 4 - Boron Releases $\underset{\text { EA glass }}{\text { (ppm) for Runs } 1,2 \& 3 \text { and the }}$ 
In between each run was an idling period of at least five days, during which time the melter air inleakage reoxidized the iron in the glass. Therefore, the glass collected in the first can from each run was more oxidized and more durable than glass collected in the latter cans. Within each run, the melter was fed continuously and therefore the redox ratio continued to increase until it approached a maximum. A comparison of the glasses to the EA glass shows that the glasses poured during the campaigns were considerably more durable. It should be noted, however, that even though all of the glasses were durable, most of the glass was not the typical shiny black glass that is normally produced. Instead, it had a black matted appearance.

\section{cenclusiens}

Although the sludge loading of the feed was lower and the amount of copper was higher than anticipated in the DWPF, there was no noticeable effect on the operation of the melter. During the three runs, there was little change in the amount of current required to maintain the melt at $1150^{\circ} \mathrm{C}$. This, coupled with the analysis of the melt pool samples, indicate that no copper was precipitating in the melter.

The amount leached from the glasses decreased as each run continued, but were still less than the amount leached from the EA glass. Further work will include longer studies in the research melter with proper sludge loading.

\section{References}

1 R. F. Schumacher, "Copper Solubility in DWPF, Batch 1 waste Glass - Update Report (U)," WSRC-TR-92-449, September 1992.

2 R. F. Schumacher and W. G. Ramsey, "Conditions for Precipitation of Copper Phases in DWPF Waste Glass (U)," Accepted for Publication at the 95th Annual Meeting of the American Ceramic Society, WSRC-MS-92-503, Rev. 1.

3 W. G. Ramsey and R. F. Schumzcher, "Effects of Formate and Nitrate Concentration on Waste Glass Redox at High Copper Concentration (U)," WSRC-TR-92-484, October, 1992.

4 C.M. Jantzen, N.E. Bibler, D.C. Beam, W.G. Ramsey, and B.J. Waters, "Nuclear waste Glass Product Consistency Test (PCT) Version 5.0 (U)," WSRC-TR-90-539, Revision 2, January, 1992.

5 U.S. Department of Energy, "Environmental Assessment Waste Form Selection for SRP High-Level Waste, " USDOE Report DOE-EA-0179, July, 1982 .

6 W. G. Ramsey, C. M. Jantzen, N. D. Hutson, and M. E. Smith, "Prediction of Glass Redox (Fe2+/ $\mathrm{Fe}$ ) from Formate and Nitrate Concentration in Melter Feeds (U)," WSRC-TR-92-385, August 1992. 

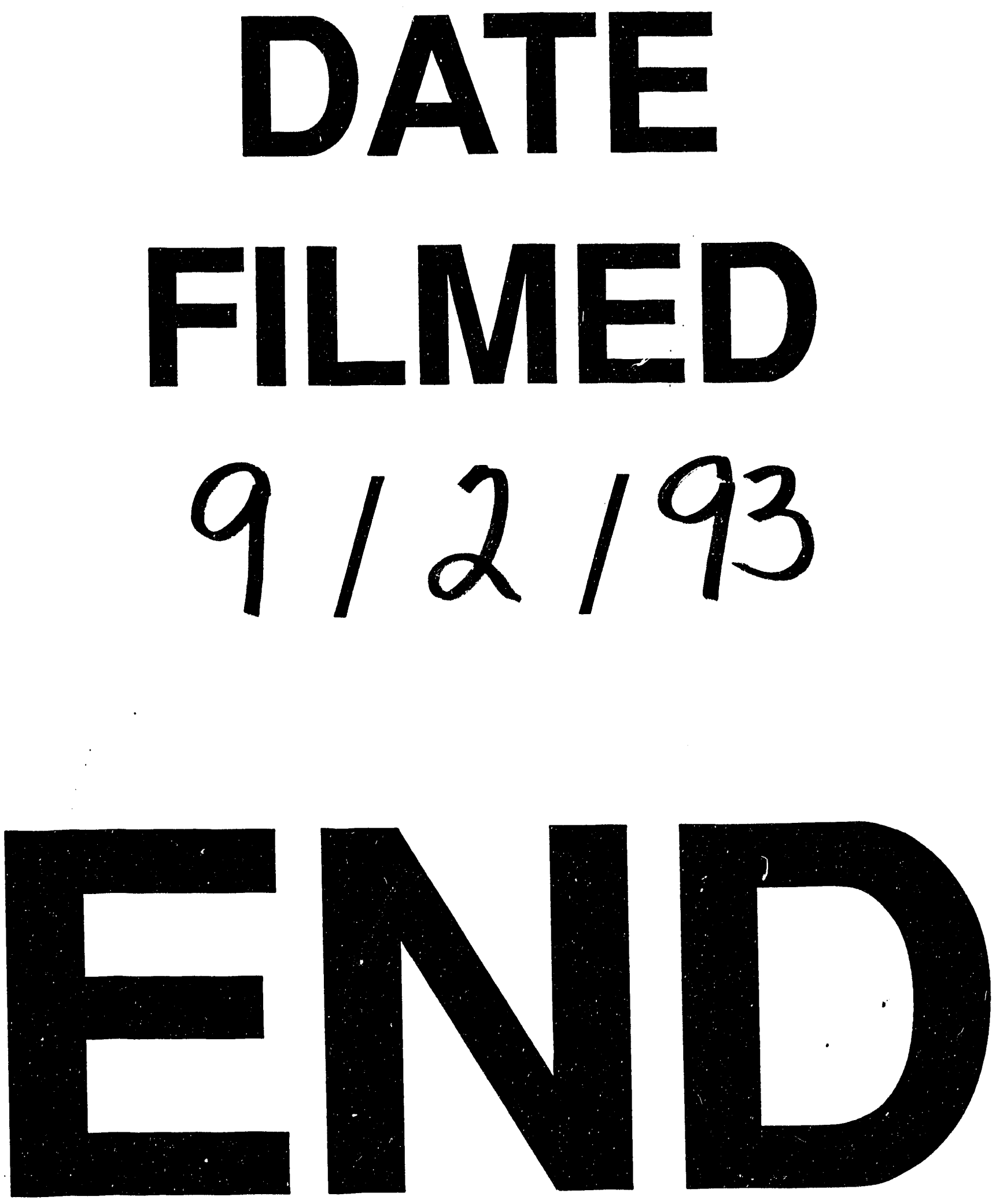
